\title{
Industrial Safety Analysis of Accidents Involving Ammonia, with Special Regard to Cold-Storage Facilities II
}

\author{
Zoltán KOCSIS, ${ }^{1}$ József DOBOR, ${ }^{2}$ Gyula KÓRÓDI, ${ }^{3}$ Enikő KUK ${ }^{4}$
}

\begin{abstract}
Anhydrous ammonia is widely used in industry (chemical industry, refrigeration technology) and it is produced, transported and used in large quantities. From the viewpoint of industrial safety, this material is essential as it is present within the area of almost every branch office of disaster management. It is a statistical fact that the number of major industrial accidents involving ammonia has not declined. The purpose of this paper is to offer a professional summary and resolution for operative professionals and decision-makers on this topic. Therefore, the closely related issues are described together with the possible solutions. This paper is the second part of a series of articles.
\end{abstract}

Keywords: ammonia, ammonium hydroxide, chemical reconnaissance, safety planning

\section{Introduction}

The paper attempts to present the whole range of the uses of anhydrous ammonia in cold storage facilities from the viewpoint of industrial safety, from safety planning to emergency responses.

Due to the complexity of the topic, the article was published in two parts. The first one described the physical and chemical hazards of ammonia together with the assessment of safety risks and the impact analysis, whereas the second one deals with safety planning and emergency response.

The Government Decree of Hungary 219/2011. (X. 20.) on the protection against major accidents involving dangerous substances regulates internal safety planning and major incident response planning in companies obliged to do so. It specifies the contents and the structure of the plans, so in line with this regulation, we wish to describe safety planning, the dangers on intervention units and the basic tasks in emergencies (intervention, first responders). [1]

Industrial safety planning - including mitigation, protection of the staff, the civilians and, last but not least, the intervention units, preparedness, prevention and response as well - is the integrated use of natural sciences, geographic information science and legal regulations. This article attempts to provide assistance and to offer a practical assessment of a dangerous

1 E-mail: kocsis@sezoged.com

E-mail: dobor.jozsef@uni-nke.hu

E-mail: korodi.gyula@uni-nke.hu

4 E-mail: kuk.eniko.eszter@uni-nke.hu 
material from the viewpoint of industrial safety and the related emergency planning procedure. All responsible business leaders have to perform industrial safety planning and this paper attempts to provide help for corporate leaders and disaster management by describing the process of industrial safety planning in dangerous industrial establishments.

\section{Safety Planning and its Contents}

According to the Government Decree 219/2011. (X. 20.) on the protection against major accidents involving dangerous substances, [1] establishments using anhydrous ammonia are identified as below tier establishments in Hungary. In this case, the establishment submits a request for a disaster management license to the competent County Directorate for Disaster Management, for which a Major Incident Response Plan (MIRP) is required. The MIRP has to comply with all the requirements for the form and content set out in the Government Decree 219/2011. (X. 20.). [2]

The establishment using anhydrous ammonia collects, systematizes and evaluates data on all its affected plants. Then, in a standard procedure it identifies its dangerous units based on Seveso-III (Directive 2012/18/EU) criteria. [16] In the designated parts of the establishment it analyses in detail and documents the technologies used, so that they are suitable for exploring all the necessary and sufficient conditions for the impacts to extend beyond the area of the establishment. In light of the conditions, it reveals the results, including the scenarios with adverse impacts, which might extend beyond the area of the establishment. With the help of an internationally accepted assessment method, it determines the frequency of occurrence of the given scenarios and in an impact analysis it identifies the consequences of the scenarios in the units dealing with dangerous materials. [1] [2]

In the light of the frequency of the occurrence and their consequences, the establishment carries out its industrial safety assessment.

Being aware of the potential major incidents and their impacts, safety planning is carried out in the form of a MIRP.

\section{Compulsory Content Points of Safety Plans}

\section{Description of the below-tier establishment and its surroundings [3]}

Methodology of the designation and assessment of a vulnerable zone: when specifying the principles and length of the assessment within the Major Incident Response Plan, the requirements set out in Act CXXVIII of 2011, [15] Directive 96/82/EC [17] and Government Decree 219/2011. (X. 20.) [1] are considered decisive.

The description has to include the following items:

- settlement planning in the vicinity of the below-tier establishment;

- the description of the dwelling area;

- a list and description of the facilities frequented by the population;

- natural areas, special natural values;

- utilities that might be affected by hazardous materials incidents;

- traffic and demographic data included in the vulnerability assessment;

- surrounding economic entities;

- hazardous activities of other operators in the vicinity of the below-tier establishment; 
Z. KOCSIS, J. DOBOR, Gy. KÓRÓDI, E. KUK: Industrial Safety Analysis of Accidents Involving Ammonia...

- description of the natural environment, meteorology and its impact on the technology;

- geology, hydrogeology and their impact on the technology;

- vulnerability of the natural environment from hazardous materials incidents.

2. Description of the below-tier establishment

General description of the activities of the below-tier establishment:

- the function of the below-tier establishment;

- the number of staff, working hours;

- the number of shifts;

- general statements on the below-tier establishment;

- description of the dangerous plants of the below-tier establishment;

- inventory of the hazardous materials present, identification, classification and quantity of the hazardous materials.

Further information to support hazard identification:

- processes involving dangerous materials and their typical parameters;

- description of the ammonia-based refrigeration system;

- storage of waste and hazardous materials;

- description of the safety and detection system of the technology;

- operational statuses other than the normal one, (temporary) storage of hazardous materials and related activities, decontamination materials at the site. [3]

3. Detailed description of the potential major incidents involving hazardous materials. Visual representation of the technologies

4. Risk assessment of major incidents involving hazardous materials

This chapter has to address the following items:

- data collection and systematization, preliminary analysis;

- inventory of the hazardous materials present;

- identification of the below-tier establishment;

- preliminary analysis based on selection and indication numbers;

- presentation of the technology in the establishment from the viewpoint of safety, determining the accident frequency rate;

- description of the methodology applied, presentation of the ammonia-based refrigeration system and determining the frequency rate of major incidents;

- the frequency analysis of endangering the neighborhood and its impact analysis;

- impact analyses of the specific scenarios;

- impact analysis of environmental pollution;

- domino effect analysis, analysis of external domino effect, analysis of internal domino effect;

- industrial safety assessment, assessment of individual and social risk. [3]

5. Forces and organizations involved in the response to major hazardous materials incidents

Leader of incident response team, incident response team (executive body), on-site resources that can be involved in the rescue, mobilizable team (intervention unit), first aider, reception, personnel working in the vulnerable zone, outside contractors or visitors, off-site resources that can be involved in the rescue, equipment that can be used in the response, infrastructure, utilities, electricity and other energy sources available for the response, backup power supply. 
Z. KOCSIS, J. DOBOR, Gy. KÓRÓDI, E. KUK: Industrial Safety Analysis of Accidents Involving Ammonia...

Fire extinguishers, fire water system, command centers in emergency, notification of management in emergency, alerting personnel in emergency, emergency communication devices and systems, evacuation shelters, technical infrastructure aiding control, situation assessment and preparation of decisions, information systems, on-site equipment available for the response.

\section{Protection tasks}

Major incidents involving hazardous materials, general code of conduct, emergency measures, alarm, immediate response to mitigate damage, escape, evacuation, follow-up activities, investigation, report, reporting obligation.

\section{Training and drills}

The organization responsible for training, the training program, its schedule, the main content points of the exercises.

\section{Safety management system}

Organization and personnel, identification and assessment of major incident risks involving hazardous materials, management of the establishment, managing changes, safety planning, internal audit and management review.

9. Organizations involved in planning

Organizations and contractors that are involved in safety planning.

10. Summary

Summarizing the organizations involved in safety planning, the purpose of the plan, the brief description and deadline of the technological modifications needed to achieve the purpose.

\section{An Example for Identifying Individual and Societal Risks}

We presented risk assessment in SAVE $\mathrm{II}^{5}$ environment to determine accident frequency studied in the first part of the paper. SAVE II is able to display the results graphically and also using vector-graphics in MIF (MapInfo Interchange File Format - MIF) format. SAVE II is a disaster management application approved by the Dutch Ministry of Infrastructure and the Environment. SAVE II is an accepted program in most countries of Europe to identify the consequences and assess the risks of incidents in dangerous establishments falling under the scope of the SEVESO directive. Risk Calculation Module of SAVE II is used to perform risk analysis. It is possible to define a model area and the density of its division. The necessary input data cover meteorological information, population information and frequency probability of the incident. A set of risk values is the output, represented as a closed curve in the $x y$ plane in the case of an individual risk, while regarding societal risks, it is represented as a smooth curve in the $\mathrm{FN}^{6}$ plane (FN-curve).

The model area is 1000 meters wide in the east-west direction, and also 1000 meters wide in the north-south direction. The area is divided up into cells of 10 meters by 10 meters. [4]

5 The SAVE II program is intended for individual and societal risks, calculation and to graphically display them. The risk of outflow, evaporation, steam, gas diffusion, fire, heat radiation and pressure, based on the analysis are set out in an explosion.

6 Societal risk can be presented by FN curves, which are plots of the cumulative frequency (F) of various accident scenarios against the number $(\mathrm{N})$ of casualties associated with the modelled incidents. 
Z. KOCSIS, J. DOBOR, Gy. KÓRÓDI, E. KUK: Industrial Safety Analysis of Accidents Involving Ammonia...

When performing risk calculations, probit values determined in the first part of the paper are used. The $a, b, n$ are probit values of ammonia are contained in standard E of CPR18.:

$\begin{array}{llll}\text { substance/effect } & \text { a } & \text { b } & \text { n } \\ \text { NH3 } & -15.6 & 1 & 2\end{array}$

All major incident scenarios, identified in the "red" zone by HAZOP analysis, were taken into consideration in the risk calculation of the given establishment, as can be seen in Figure 1.

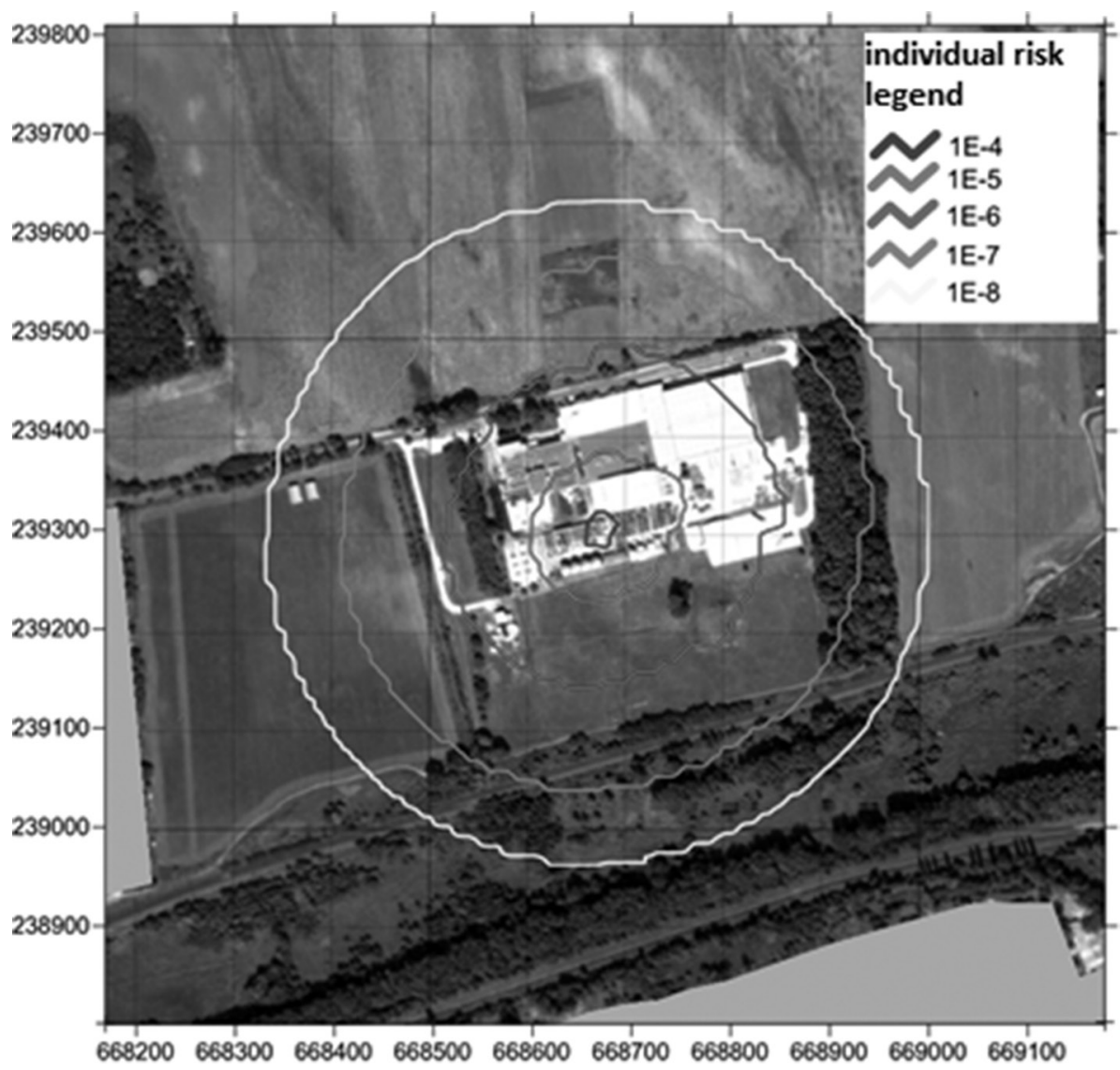

Figure 1. Individual death risk in the establishment under scrutiny represented on a map. [18]

The danger zone with $10^{-6}$ fatalities/year does not affect residential areas. According to the Governmental Decree 219/2011. (X. 20.), [1] individual risk can be accepted without conditions provided the residential area is in a zone with a lower risk than $10^{-6}$ fatalities/year resulting from major incidents involving hazardous materials. [5] 
Z. KOCSIS, J. DOBOR, Gy. KÓRÓDI, E. KUK: Industrial Safety Analysis of Accidents Involving Ammonia...

\section{Determining Societal Risk}

Societal risk is assessed on the basis of Governmental Decree 219/2011. (X. 20.). [1] Upon calculating it, the population of the danger zone as well as people temporarily staying there (at work/school, in shopping malls or entertainment facilities) are taken into account. The result is depicted in an FN-curve.

$\mathrm{X}$-axis of the FN-curve represents the number of deaths $(\mathrm{N})$. The number of deaths is represented on a logarithmic scale, where the lowest value is 1 . Y-axis of the FN-curve shows the total frequency of incidents with $\mathrm{N}$ or more number of deaths. These values are represented on a logarithmic scale as well, where the lowest value is $10^{-9}$ incidents/year, as can be seen in Table 1. [6]

Table 1. Societal risk and assessment. [6]

\begin{tabular}{|l|l|}
\hline Societal risk & Assessment \\
\hline$F<\left(10^{-5} \times N^{-2}\right) 1$ year, where $N>=1$ & Acceptable without conditions \\
\hline $\begin{array}{l}\text { in the range of } F<\left(10^{-3} \times N^{-2}\right) 1 / \text { year and } F>\left(10^{-5} \times N^{-2}\right) \\
1 / \text { year, where } N>=1\end{array}$ & Acceptable with conditions \\
\hline$F>\left(10^{-3} \times N^{-2}\right) 1$ year, where $N>=1$ & Not acceptable \\
\hline
\end{tabular}

When assessing societal risk, an identical model area to the one described in the calculation of individual risk was used. Risk curves do not affect residential areas or places of assembly. However, they do affect railway line 80A Budapest - Hatvan - Miskolc. Although, there is no exact traffic data available on this line, according to the current railway schedule, altogether 44 trains travel on the affected route every workday. [6]

\section{Risk Directly Affecting Operative Units}

Incidents involving hazardous materials pose various types of threats to the quality of human life. Often several risks are present at the same time, which may be the following, as can be seen in Table 2.

Table 2. Typical hazards of ammonia. [7]

\begin{tabular}{|l|l|}
\hline (Physical) Effects of an explosion & $\begin{array}{l}\text { shockwave and flying debris as well as high tempera- } \\
\text { ture }\end{array}$ \\
\hline Effects of intoxication & $\begin{array}{l}\text { toxic materials may enter the body through inhalation } \\
\text { on skin absorption }\end{array}$ \\
\hline Effects of suffocation & lack of oxygen because of the smoke or the gas leak \\
\hline Effects of fire/heat & $\begin{array}{l}\text { threats related to the heat and fire are the burning gas- } \\
\text { es, liquids or powders (e.g. liquid gas, oil or carbon } \\
\text { powder) }\end{array}$ \\
\hline Effects of oxidation & $\begin{array}{l}\text { threats related to flammable materials (oxidants), } \\
\text { which can result in increased burning and heat }\end{array}$ \\
\hline
\end{tabular}


Z. KOCSIS, J. DOBOR, Gy. KÓRÓDI, E. KUK: Industrial Safety Analysis of Accidents Involving Ammonia...

\begin{tabular}{|l|l|}
\hline Effects of chemicals & $\begin{array}{l}\text { contact with acids and bases can cause damage to the } \\
\text { skin, eye or mucosal surfaces }\end{array}$ \\
\hline Effects of freezing & $\begin{array}{l}\text { frozen liquid spills or high pressure gas leaks may } \\
\text { cause frostbite }\end{array}$ \\
\hline Effects of infection & body becomes infected \\
\hline Threats on the environment & risk of water, soil or air pollution \\
\hline
\end{tabular}

\section{Management of Incidents in Cold-Storage Facilities}

The above mentioned physical, chemical and biological risks have to be considered when the intervention is planned. In incidents involving anhydrous ammonia, like in other incidents, the top priority is to rescue the victims. All the other tasks are preceded by it or performed for this purpose. Response plans for accident scenarios described in MIRP greatly help actual incident management, so in this paper the main sections are highlighted, such as reconnaissance, rescue and intervention strategies. [8]

\section{Reconnaissance}

The primary task is to organize and perform reconnaissance, which always has to cover the following items:

- the number and location of the injured or the victims stuck inside (based on a headcount or consulting with the rescued victims);

- the location and direction of the exit and the extent of the damage to the technology;

- the concentration levels (identifying zones);

- description of the area (drainage map, slope of the area, accessibility of the routes, as it can happen that in case of a spill in the engine room or the refrigeration room, the extent of the damage can be decreased by blocking the doors and the ventilation).

In a corporate environment (in dangerous establishments, in below-tier establishments) the potential incidents involving hazardous materials are allocated codes in the scenarios. To compile a database, only the necessary and sufficient information should be collected. In an accident, collecting unreasonably too much data can be a waste of time and does not facilitate emergency management in effect. If the continuous communication between the leaders of the incident response team and the reconnaissance team is guaranteed, the leader of the response team has to help limit information in order to identify the scenario by adhering to unambiguous questions. [9]

In practice, reconnaissance, assessment, decision making and command form a continuous, so-called tactical cycle. The external parameters affecting the course of the accident can change for multiple reasons and the leader of the response team has to respond to these changes. He has to notice them and adapt to the changing circumstances.

The "situation" thus covers all the factors that must be taken into account during the intervention to avert and overcome dangers.

The situation is determined by:

- the incident and the inherent risks;

- the necessary response, which specifies the intervention personnel and equipment. 
Z. KOCSIS, J. DOBOR, Gy. KÓRÓDI, E. KUK: Industrial Safety Analysis of Accidents Involving Ammonia...

The situation is influenced by: the "general situation" (location, time, weather, number of staff, etc.).

At the scene of the fire or the accident, we have to be prepared for special circumstances in the presence of anhydrous ammonia. A smooth intervention can be expected if:

- the training and experience of the intervention team includes knowledge about hazardous materials;

- the equipment (personal protective equipment and other tools) are suitable for special interventions involving hazardous materials;

- extinguisher suitable for flammable materials is available.

From the viewpoint of the response team, it is important for them to become acquainted with the whole cycle, including the stages of compressed gas, compressed liquid and vacuumed gas. [8]

\section{Specifying Personal Protection \\ Points to Consider when Choosing Protective Equipment}

In the case of intoxication, it is essential how long the human body is exposed to the effects of the toxic materials like ammonia, which is called exposure. The leader of the response team can determine the level of protection with the help of Table 3.

Table 3. Concentration of anhydrous ammonia vapor and its effects on the human body. [10]

\begin{tabular}{|l|l|l|}
\hline $\begin{array}{l}\text { Exposure (ppm)/ } \\
\text { percent by volume (m/m \%) }\end{array}$ & Effect on the Body & Permissible Exposure \\
\hline $\begin{array}{l}25 \mathrm{ppm} \\
0.0025 \text { percent by volume }\end{array}$ & $\begin{array}{l}\text { Adverse effects highly un- } \\
\text { likely }\end{array}$ & - \\
\hline $\begin{array}{l}50 \mathrm{ppm} \\
0.005 \text { percent by volume } \\
\text { sons. Some people complain } \\
\text { of nose irritation after } 5 \text { min- } \\
\text { utes of exposure }\end{array}$ & $\begin{array}{l}\text { No injury from prolonged, } \\
\text { or repeated exposure }\end{array}$ \\
\hline $\begin{array}{l}134 \text { ppm } \\
0.0134 \text { percent by volume }\end{array}$ & $\begin{array}{l}\text { Most people experience dry- } \\
\text { ness and irritation of nose, } \\
\text { throat and eyes }\end{array}$ & $\begin{array}{l}\text { Eight hours maximum expo- } \\
\text { sure }\end{array}$ \\
\hline $\begin{array}{l}400 \text { ppm } \\
0.04 \text { percent by volume }\end{array}$ & Moderate throat irritation & - \\
\hline $\begin{array}{l}500 \text { ppm } \\
0.05 \text { percent by volume }\end{array}$ & $\begin{array}{l}\text { Immediately dangerous to } \\
\text { life or health (IDLH) }\end{array}$ & $\begin{array}{l}\text { One hour maximum expo- } \\
\text { sure }\end{array}$ \\
\hline $\begin{array}{l}700 \text { ppm } \\
0.07 \text { percent by volume }\end{array}$ & $\begin{array}{l}\text { Coughing. Severe eye irrita- } \\
\text { tion, if not treated, may lead } \\
\text { to partial or total loss of sight }\end{array}$ & $\begin{array}{l}\text { One hour maximum expo- } \\
\text { sure }\end{array}$ \\
\hline $\begin{array}{l}1000 \text { ppm } \\
0.1 \text { percent by volume }\end{array}$ & Directly caustic to airway & No exposure permissible \\
\hline
\end{tabular}


Z. KOCSIS, J. DOBOR, Gy. KÓRÓDI, E. KUK: Industrial Safety Analysis of Accidents Involving Ammonia...

\begin{tabular}{|l|l|l|}
\hline $\begin{array}{l}1,700 \mathrm{ppm} \\
0.17 \text { percent by volume }\end{array}$ & $\begin{array}{l}\text { Serious lung damage, death } \\
\text { unless treated } \\
\text { Laryngospasm }\end{array}$ & No exposure permissible \\
\hline $\begin{array}{l}2000 \mathrm{ppm} \\
0.2 \text { percent by volume }\end{array}$ & $\begin{array}{l}\text { Burns and blisters skin after } \\
\text { a few seconds of exposure }\end{array}$ & No exposure permissible \\
\hline $\begin{array}{l}5000 \mathrm{ppm} \\
0.5 \text { percent by volume }\end{array}$ & $\begin{array}{l}\text { Death by suffocation within } \\
\text { minutes }\end{array}$ & No exposure permissible \\
\hline
\end{tabular}

In interventions involving hazardous materials, personal protection is of utmost importance. No intervention can be conducted in the vicinity of hazardous materials without protective equipment. On the basis of the risk level and worker comfort, four levels of protection can be differentiated, as can be seen in Table 4 .

Table 4. Levels of protection recommended by EPA (it is valid for ammonia too). [11]

\begin{tabular}{|c|c|c|c|}
\hline $\begin{array}{l}\text { Level A protection } \\
\text { (This level is } \\
\text { preferred in the pres- } \\
\text { ence of ammonium } \\
\text { gas.) }\end{array}$ & Level B protection & Level C protection & Level D protection \\
\hline $\begin{array}{l}\text { encapsulating, } \\
\text { whole-body chemi- } \\
\text { cal protective heavy } \\
\text { garment (with insu- } \\
\text { lation) } \\
\text { self-contained com- } \\
\text { presses air breathing } \\
\text { apparatus with a full } \\
\text { face mask } \\
\text { boots providing } \\
\text { chemical and me- } \\
\text { chanical protection } \\
\text { double layer protec- } \\
\text { tive gloves } \\
\text { protective helmet } \\
\text { communication } \\
\text { device }\end{array}$ & $\begin{array}{l}\text { encapsulating, } \\
\text { whole-body chem- } \\
\text { ical protective gar- } \\
\text { ment (with insula- } \\
\text { tion or filtration) } \\
\text { self-contained com- } \\
\text { presses air breathing } \\
\text { apparatus with a full } \\
\text { face mask } \\
\text { boots providing } \\
\text { chemical and me- } \\
\text { chanical protection } \\
\text { double layer protec- } \\
\text { tive gloves } \\
\text { protective helmet } \\
\text { communication } \\
\text { device }\end{array}$ & $\begin{array}{l}\text { encapsulating, } \\
\text { whole-body chem- } \\
\text { ical protective gar- } \\
\text { ment (with insula- } \\
\text { tion or filtration) } \\
\text { full face gas mask } \\
\text { with adequate filters } \\
\text { boots providing } \\
\text { chemical and me- } \\
\text { chanical protection } \\
\text { double layer protec- } \\
\text { tive gloves } \\
\text { protective helmet } \\
\text { communication } \\
\text { device }\end{array}$ & $\begin{array}{l}\text { whole-body chem- } \\
\text { ical protective light } \\
\text { garment (with insu- } \\
\text { lation or filtration) } \\
\text { full face or half face } \\
\text { gas mask with ad- } \\
\text { equate filters (with } \\
\text { safety glasses) } \\
\text { protective boots } \\
\text { protective gloves } \\
\text { protective helmet }\end{array}$ \\
\hline
\end{tabular}

Out of the levels of protection, the most optimal has to be selected by considering safety, worker comfort and financial factors.

When wearing gas-tight protective clothing, calculating with an average rate of work, at least 10 minutes have to be allocated for chemical decontamination after performing the intervention. 
Z. KOCSIS, J. DOBOR, Gy. KÓRÓDI, E. KUK: Industrial Safety Analysis of Accidents Involving Ammonia...

\section{Life-Saving}

Although chronologically lifesaving is preceded by some other tasks, it comes first in the order of priorities even in an intervention involving hazardous materials for both humanitarian and legal reasons.

Victims can be considered in immediate danger to life if they cannot escape by their own efforts without help, which can cause their death or severe injuries.

Victims are in indirect danger to life if the can escape on their own from a direct danger or if without being rescued, the danger would become immediate. Both types of victims must be rescued. These factors also have to be examined when the rescue order is determined. [12] The symptoms of ammonia intoxication are summarized in Table 5.

Table 5. Symptoms of ammonia intoxication. [13]

\begin{tabular}{|l|l|}
\hline Airways, lungs, and chest: & Cough \\
& Chest pain (severe) \\
& Difficulty breathing \\
& Rapid breathing \\
& Wheezing \\
\hline Body-wide: & Fever \\
\hline Eyes, ears, nose, mouth, and throat: & Tearing and burning of eyes \\
& Temporary blindness \\
& Throat pain (severe) \\
& Lip swelling \\
\hline Heart and blood: & Rapid, weak pulse \\
& Collapse and shock \\
\hline Nervous system: & Confusion \\
& Difficulty walking \\
& Lack of coordination \\
& $\begin{array}{l}\text { Restlessness } \\
\text { Stupor (altered level of consciousness) }\end{array}$ \\
\hline Skin: & Bluish-colored lips and fingernails \\
& Severe burns if contact is longer than a few minutes \\
\hline Stomach and gastrointestinal tract: & Severe stomach pain \\
& Vomiting \\
\hline
\end{tabular}

\section{Designating Escape Routes and Assembly Points}

Designated escape routes and evacuation assembly points must be accessible at all times. Always the safest routes have to be designated for rescue. Special attention has to be paid for the direction the hazardous material like ammonia spreads in, its location and based on them, the protection and decontamination of the victims must also be taken care of. Before life-saving, proper medical care has to be arranged for, so that the victims can be provided with immediate care after being rescued. When designating the escape routes, it has to be en- 
sured that rescue and other activities do not interfere with each other. It would be reasonable to assign a rescue commander in the command team, who organizes and coordinates these activities to make them more transparent. The next part summarizes the urgent tasks in the case of ammonia intoxication.

What to do in case of ammonia intoxication? [14]

- When ammonia poisoning is suspected, victims should be led out of the contamination zone as quickly as possible.

- It is important that those helping them should be wearing adequate protective clothing, so as not to become victims themselves.

- Oxygen - if it is available - must be administered to victims while rescuers await the arrival of an ambulance.

- Irritated eyes must also be flushed with plain or saline water for 5 minutes. Remove contact lenses if they are being worn by affected persons.

- If there has been skin contact with ammonia, it is essential that the skin be decontaminated as quickly as possible. Clothing must be removed and the skin must be flushed with water for at least 5 minutes.

\section{Performing Rescue}

The command team and the intervention units have to pay due attention to the fact that they are responsible for not just their own safety, but also that of the citizens, the passers-by and the staff. Even if legally not spelled out, practically the rescuers are also part of the response and they can facilitate it with their attitude and prior knowledge. The entire personnel involved in the response have to be prepared for life-saving, which entails a significant amount of regular trainings together with the appropriate technical background. They need to have a thorough, practical, effective knowledge of the use of rescue equipment as well as the basic and special rules of the rescue. Long and frequent practice is needed until the use of rescue equipment becomes automatic. It is indispensable in the rescue of victims in potentially poor psychological conditions.

A certain amount of pedagogical knowledge might also be useful, because the victims to be rescued have to be provided with certain information, otherwise they would be less willing to cooperate. Little time is available to communicate relevant, brief information, which should be sufficient to start the rescue of the victim.

\section{The Strategy and Tactics of the Intervention}

The success of the intervention basically depends on the smooth operation of command and control. The incident commander is responsible for everything that happens during the intervention, thus for the effectiveness of the intervention. Intervention strategy incorporates all the goals of economic entities that aim at successful response, set out in the disaster management act. This strategy is realized by certain tactical elements. The tactics of the intervention encompasses a set of actions following a series of decisions, which deploy the right forces and resources to the right place at the right time. Thus, the incident is resolved within the shortest possible time without causing further damage. [8] [9] 
Z. KOCSIS, J. DOBOR, Gy. KÓRÓDI, E. KUK: Industrial Safety Analysis of Accidents Involving Ammonia...

\section{Tactical methods}

Defensive method includes:

- eliminating ignition sources;

- vapour suppression (dilution with water mist, controlling direction of flow);

- confinement or diversion, within the defined area;

- information;

- evacuation if needed.

Offensive method includes the following (the list is not inclusive):

- trouble-shooting to slow down or stop the leakage;

- keeping materials closed in their own container or package;

- clean-up processes. [8] [9]

\section{Conclusions}

The success of the intervention is primarily dependent on the smooth operation and effectiveness of the intervention units. It is important to note that the incident commander bears responsibility for everything that happens until somebody else takes over control. All types of ammonia scenarios are possible in cold-storage facilities due to the technology used. As can be seen in Figure 1, depending on the concentration, it can be immediately lethal or it may not even pose a health risk. A characteristic of ammonia incidents in cold-storage facilities is that the release can be liquid, vapor as well as gas, but the incidents are well manageable with proper reconnaissance, protective equipment, tactics and the suitable plans. It is of utmost importance that the first responders are well-prepared, their equipment is well-maintained and proper for the intervention.

The Government Decree of Hungary 219/2011. (X. 20.) on the protection against major accidents involving dangerous substances [1] requires establishments using a dangerous amount of ammonia to assemble and train an incident response team. The potential incident scenarios are detailed in the Internal Safety Plan (ISP) or in the Major Incident Response Plan. The Firefighting and Technical Rescue Plan (FTRP), which is based on ISP and MIRP, together with the joint drills ensure successful interventions. The authors plan to continue this series of articles, focusing on industrial accidents involving ammonia.

\section{References}

[1] Government Decree 219/2011. (X. 20.) on the protection against major accidents involving dangerous substances.

[2] KORDA E.: Küszöbérték alatti üzemek azonosítása és elemzése. Budapest: Generisk Kft., 2012.

[3] US OSHA: Occupational Safety and Health Program. Washington, D.C.: US Government Occupational Safety and Health Administration, s.d.

[4] Accidental Risk Assessment Methodology for Industries in the Context of the Seveso II Directive “ARAMIS". 2004.

[5] SCHÜLLER, C. H., BRINKMAN, J. L., GESTEL, van P. J., OTTERLOO, van R. W.: Methods for Determining and Processing Probabilities (Red Book). Den Haag: Ministerie van Verkeer en Waterstaat, 1997. 
Z. KOCSIS, J. DOBOR, Gy. KÓRÓDI, E. KUK: Industrial Safety Analysis of Accidents Involving Ammonia...

[6] UIJT de HAAG, P. A. M., ALE, B. J. M.: Guidelines for quantitative risk assessment “Purple Book”. Den Haag: Ministerie van Verkeer en Waterstaat, 2005.

[7] PHE CRCE: Ammonia. Toxicological Overview. Didcot: Public Health England, Centre for Radiation, Chemical and Environmental Hazards, 2015. www.gov.uk/government/uploads/ system/uploads/attachment_data/file/455704/Ammonia_TO_PHE_240815.pdf (downloaded: $30012015)$

[8] KORDA E., KOCSIS Z.: Vállalati elsődleges beavatkozók. Budapest: Generisk Kft., 2013.

[9] FEMA: Hazardous Materials Guide for First Responders. Washington, D.C.: Federal Emergency Management Agency United States Fire Administration, 2012.

[10] NOWATZKI, J. F.: Managing the Risks North Dakota State University and U.S. Department of Agriculture. Fargo: North Dakota State University, 2013.

[11] US OSHA: EPA levels of protection. 1991. www.osha.gov/pls/oshaweb/owadisp.show_ document?p_table=MOU\&p_id=238 (downloaded: 3001 2015)

[12] Ministry of Interior Decree 39/2011. (XI. 15.) on the general rules of firefighting and technical rescue.

[13] US NATIONAL LIBRARY OF MEDICINE: Ammonia poisoning. www.nlm.nih.gov/ medlineplus/ency/article/002759.htm (downloaded: 3001 2015)

[14] ATSDR: ToxFAQs ${ }^{\mathrm{TM}}$ for Ammonia. Atlanta: Agency for Toxic Substances and Disease Registry, 2004. www.atsdr.cdc.gov/toxfaqs/tfacts126.pdf (downloaded: 3001 2015)

[15] 2011. évi CXXVIII. törvény a katasztrófavédelemről és a hozzá kapcsolódó egyes törvények módosításáról.

[16] Directive 2012/18/EU of the European Parliament and of the Council of 4 July 2012 on the control of major-accident hazards involving dangerous substances, amending and subsequently repealing Council Directive 96/82/EC (1). Official Journal of the European Union, 55 (2012), 1-37.

[17] Council Directive 96/82/EC of 9 December 1996 on the control of major-accident hazards involving dangerous substances. Official Journal, 01 (1997), 1-33.

[18] Generisk Kft. www.generisk.hu/index.html (downloaded: 3001 2015) 